\title{
Heat behavior analysis of nickel metal hydride batteries for electric vehicles
}

\section{電気自動車用ニッケル金属水素化物電池の発熱解析}

\author{
Noboru SATO \\ HONDA R\&D Co., Ltd. Tochigi R\&D Center \\ 4630 Shimotakanezawa, Haga-machi, Haga-gun, Tochigi, 321-3393 JAPAN \\ TEL: 81-28-677-6781 FAX: 81-28-677-6790 e-mail:noboru_sato@n.t.rd.honda.co.jp
}

( Received 28, August 1998 Accepted 9, November 1998 )

\begin{abstract}
Battery development for EV application is quite different from that of consumer battery. In particular, temperature conditions affect battery performances like a cycle life or an energy efficiency remarkably in accordance with a heat generation due to batteries themselves. Accordingly, heat management technologies including the development of battery materials, the structural design of battery module or pack, and the installing system are strongly demanded. The heat behavior of Ni-MH batteries during charge and discharge processes was analyzed and discussed. Heat elements were basically divided to four types of factors corresponding to a battery reaction heat: $Q_{r}$, a polarization heat: $Q_{p}$, a sub reaction heat: $Q_{s}$ and a joule heat: $Q_{j}$. To minimize the $Q_{s}$ by introducing an undercharge or a minimum overcharge is effective in order to reduce a heat generation and to increase an energy efficiency during a charge process. And a control technology of oxygen generation from positive electrodes due to a sub reaction of water decomposition is imperative. As an internal resistance of battery dominates a heat generation relating a joule heat and a polarization heat at charge and discharge processes. Eventually, both the material development and the control technology like a charge algorithm should be considered to suppress the total heat generation.
\end{abstract}

Keywords : Nickel metal hydride battery, Electric vehicle, Heat behavior, Heat management,

Exothermic reaction, Endothermic reaction, Entropy control

\section{INTRODUCTION}

近年、電気自動車の開発がしのぎを削っているなか、エネ ルギー領域としての電池技術の進化が目覚しい。従来型の鉛 電池から、高性能タイプのNi-MH電池、リチウムイオン電池 (Liイオン)、ナトリウム塩化ニッケル電池 $\left(\mathrm{Na}-\mathrm{NiCl}_{2}\right)$ などの 系統に大きな期待が寄せられている。なかでも Ni-MH電池は 性能、信頼性、安全性の面で一歩抜きんでており、実用化と いう観点ではFig.1に示す“HONDA EV PLUS”に搭載され、カ リフォルニアの市場で既に二年を経過した。このNi-MH電池 は、10セル単位、12Vのモノブロックモジュールの直列接続 で、計24モジュール、すなわち総電圧 $288 \mathrm{~V}$ 総重量 $480 \mathrm{~kg}$ の 大型電池群から構成されている。

しかしNi-MHやLiイオン電池のような常温型電池は熱の影 響を受け易く、特に $50^{\circ} \mathrm{C}$ 以上の領域では充電効率や寿命特性 が低下する場合があり、発熱制御が重要になってくる。ま た、電池系に応じて発熱挙動が大きく変わることから、電池 反応や発熱因子を十分に考慮したうえでの熱マネージメント が必要になる。しかしながら、これまでに電気自動車用電池 の熱挙動を扱った論文はほとんどなく、リチウム電池で一部

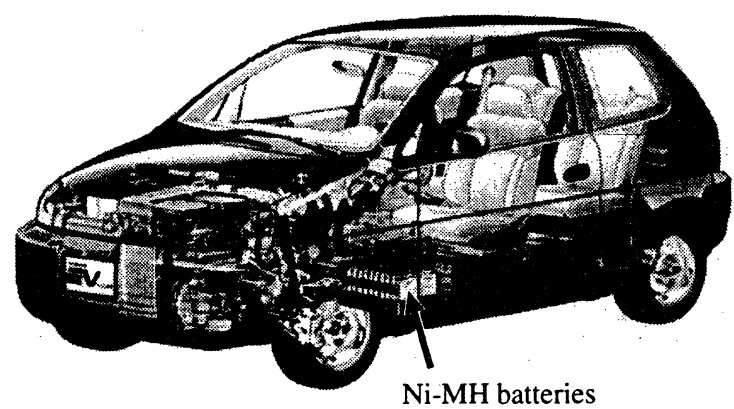

FIG.1. "HONDA EV PLUS".

報告されているにすぎなかった。1本報告では、1991年より 開発に取り組んできた電気自動車用Ni-MH電池の充放電時の 反応、内部抵抗などの熱因子を詳細に解析することで、これ まで明らかにされていなかった発熱機構を解析し、さらにそ の制御技術についての知見を述べる。 
II. PRINCIPLE OF NI-MH BATTERY AND HEAT GENERATION 水酸化ニッケル $\mathrm{Ni}(\mathrm{OH})_{2}$ の正極と水素吸蔵合金の負極拉よ び水酸化カリウムと水酸化リチウムの水溶液を電解液とする $\mathrm{Ni}$-MH電池の充放電反応は (1) および ( 2 )式で表される。

$$
\text { 正極: } \mathrm{NiOOH}+\mathrm{H}_{2} \mathrm{O}+\mathrm{e} \rightleftarrows \mathrm{Ni}(\mathrm{OH})_{2}+\mathrm{OH}^{-}
$$$$
\text { 負極： } \mathrm{MH}+\mathrm{OH}^{-} \quad \rightleftarrows \mathrm{M}+\mathrm{H}_{2} \mathrm{O}+\mathrm{e}
$$

すなわち、Fig. 2に示す水酸化ニッケルは充電時に水素 $(\mathrm{H})$ イオンを放出し、オキシ水酸化ニッケルとなり、一方の水素 吸蔵合金はFig.3に示す構造で、充電時にH原子を吸蔵する Sol id State反応である。詳細な正極の状態変化はFig.4のよ うに表され、したがってニッケルの価数は 2 価(厳密には 2.2 価)から 3 価(厳密には3.4価)まで変化する。

一般に電池は充放電反応の段階で、発熱または吸熱を伴 う。電池反応における発熱は、可逆電池が定温定圧での熱力 学的関係を保ち、その結果、電気的仕事に相当するギブスの 自由エネルギー変化 $\Delta G に よ り(3)$ 式で表現される。

$$
\Delta G=\Delta H-T \Delta S
$$

ここで $\Delta H は$ 電池反応のエンタルピ変化、Tは絶対温度、 $\Delta S$ は電池反応のエントロビ変化である。電池反応が可逆的に進 行する場合、充電時と放電時とでは反応が逆になるため熱の 出入りも逆になる。（3）式の $T \Delta S か ゙$ 電池反応における熱エネ ルギーに相当し電池反応熱 $Q_{r}$ とし $(4)$ 式で表現される。

$$
Q_{\mathrm{r}}=T \Delta S=T(-\delta \Delta G / \delta T)
$$

一方、 $\Delta G$ は電池の起電力を $E_{e}$ 、ファラディ定数を $F 、$ 電池 反応に関与する電荷数をnとすると ( 5 )式が成立するため、 (4)式は (6)式に変換できる。

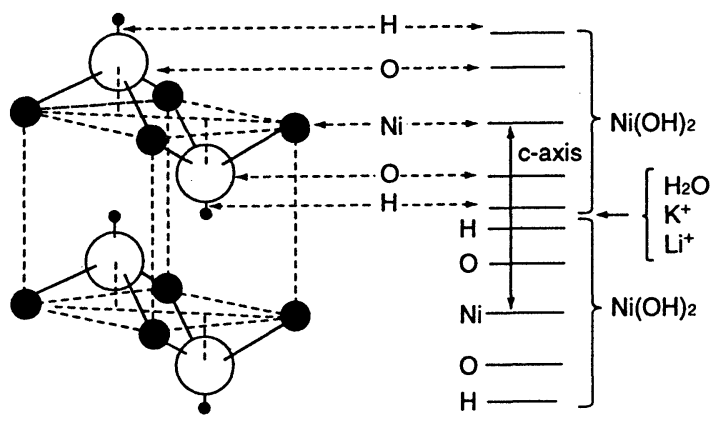

FIG.2. Crystal structure of nickel hydroxide as positive active material. $^{2}$

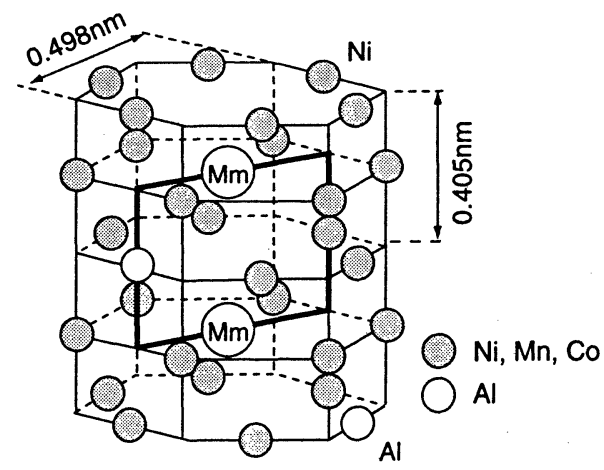

FIG.3. Crystal structure of metal hydride alloys as negative active material. ${ }^{3}$

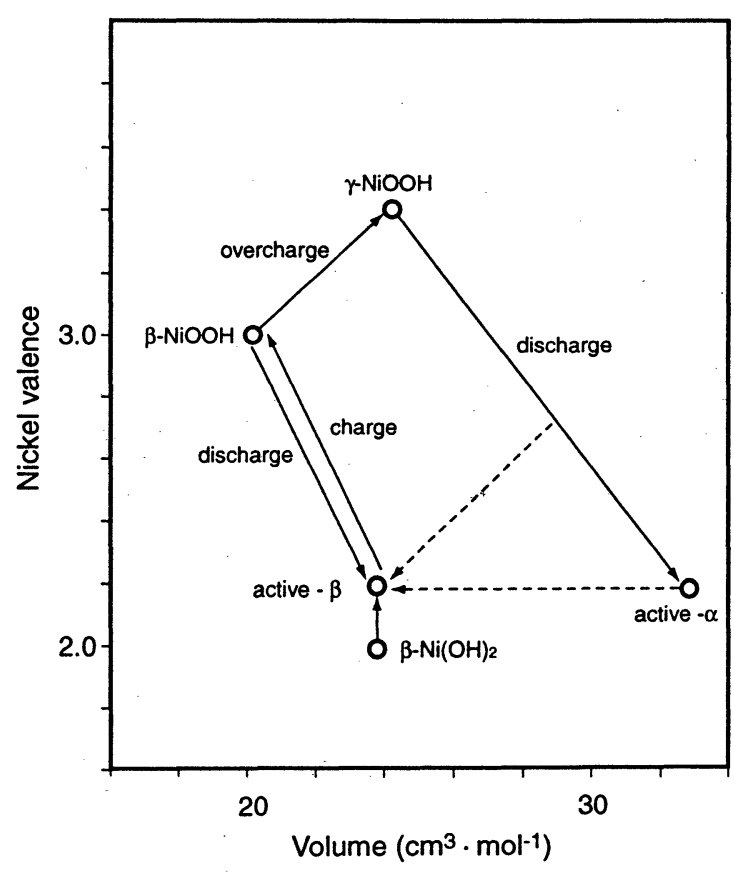

FIG.4. Chemical status of positive electrode during charge and discharge processes. ${ }^{2}$

$$
\begin{aligned}
& \Delta G=-n F E_{e} \\
& Q_{r}=n F T\left(\delta E_{e} / \delta T\right)
\end{aligned}
$$

しかし、実際の電池の端子電圧Efは電池の電気化学的分極 によって電極電位である平衡起電力からずれるため、この分 極によるエネルギー損失分の発熱 $Q_{p}$ を伴うことになる。この $Q_{p}$ は充電時も放電時も発熱である。さらに電池反応では電解 液の分解による副反応や自己放電なども生じ、これらに相当 する $Q_{s}$ の熱因子が現れる。また電池の電気的抵抗成分がもた らすジュール熱 $Q_{j}$ む加わるため、電池反応の総発熱量 $Q_{t}$ は ( 7 )式で表現される。

$$
\begin{aligned}
Q_{t}=Q_{r}+Q_{p}+Q_{s}+Q_{j}= & \\
& n F T\left(\delta E_{e} / \delta T\right)-n F\left(E_{e}-E_{f}\right)+Q_{s}+Q_{j}
\end{aligned}
$$

\section{HEAT BEHAVIOR ANALYSIS OF NI-MH BATTERY}

$A$. Heat behavior analysis during charge and discharge 充電時での反応では電池反応熱成分 $Q_{r}$ は発熱となるため、 (7)式の項の中では主要因子となる。また充電後期では電解 液の分解に伴う副反応が現れ、さらに過充電領域では電解液

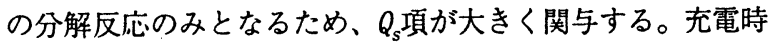
の電流と電気抵抗成分によって決まるジュール熱は充電電流 を固定すると固有値になる。放電時では電池反応熱成分 $Q_{\mathrm{r}}$ が 吸熱となるため、充電時に比べて電池反応から生じる熱スト レスはない。自己放電などの大きな電池ではこれに相当する 吸熱も無視できなくなるが、現在実用化されているNi-MH電 池の自己放電は小さく、熱挙動を解析する上では無視できる レベルにある。また正常放電の場合には電解液の分解に伴う 副反応などは現れないため、Q 逆に、放電時は電気自動車の走行段階での取り出し電流に左 右され、加速時等に大電流が流れる段階でジュール熱として 発熱する分が無視できなくなる。以上のように、充電時と放 電時では関連する支配的な熱因子が異なってくることに注目 する必要がある。 


\section{B. Analysis of heat factors}

\section{Reaction heat of battery: $Q$,}

$\mathrm{Ni}-\mathrm{MH}$ 電池における反応熱は、上記 (2)式の充電時に水素 吸蔵合金が水素原子を取り込み、金属水素化物になる際の発 熱であり、これと等価の吸熱が放電時に生じることになる。 (8)式で表現される熱量Q1は、水素吸蔵合金の組成により一 義的に決まる固有值を示す。

$$
\mathrm{M}+\mathrm{H} \rightarrow \mathrm{MH}+\mathrm{Q}_{1}
$$

実用化された Ni-MH電池の負極は $\mathrm{Mm}(\mathrm{Ni}, \mathrm{Al}, \mathrm{Co}, \mathrm{Mn})_{5}$ 系の $\mathrm{AB}_{5}$ 型希土類合金であり、その生成熱Q1 る。電池の充電時電流を $I_{c}$ とすれば、これに伴う単位時間当 たりの電池反応熱Q $Q_{r}$ は $(9)$ 式のように計算される。

$Q_{\mathrm{r}}=29.3[\mathrm{~kJ} / \mathrm{mol}] /(96487[\mathrm{~A} \cdot \mathrm{s} / \mathrm{mol}] / 3600[\mathrm{~s} / \mathrm{h}])$

$\cdot 1 / 2 \cdot I_{c}=0.547 \cdot I_{c}[\mathrm{~kJ} / \mathrm{h}]$

すなわち単位時間当たりの電池反応熱は充電電流の一次関数 で表現される。

\section{Polarization loss heat: $Q_{p}$}

実際の電池反応で理論起電力からずれる分極の原因は、電 池反応過程で原子の拡散や移動に要するエネルギーが必要と されるためである。Ni-MH電池の場合は、正極と負極との間 で行き交う水素 $(\mathrm{H})$ 原子の拡散や移動が支配因子になる。ま た水素吸蔵合金は組成系によってサイクルの経過とともに酸 化されやすいものもあり、この場合、分極が増大していく原 因となる。発熱制御の観点からは、分極の小さな組成系の設 計が鍵になる。

もっとも、この分極に伴う抵抗成分 $R_{p}$ は、電池の全内部抵 抗 $R_{t}$ の一部に相当する反応抵抗成分として出現することか ら、電気的抵抗成分を $R_{e}$ と表現すると $R_{p}$ は (10)式のように表 され、この時の単位時間当たりの分極損失熱 $Q_{p}$ は放電電流を $I_{d}$ とすると(11)式となる。充電の場合も $I_{d}$ を $I_{c}$ に置き換える だけで同一になる。

$$
\begin{gathered}
R_{p}=R_{t}-R_{e} \\
Q_{p}=I_{d}^{2} \cdot R_{p}[\mathrm{~W}]=3.595 \cdot I_{d}^{2} \cdot R_{p}[\mathrm{~kJ} / \mathrm{h}]
\end{gathered}
$$

しかしこの発熱量は全ジュール熱として出現するため、分 極損失発熱 $Q_{p}$ は直接求めることはできなく、(10)式の全抵抗 成分から分極抵抗成分を分離し、その抵抗成分に相当する発 熱量として算出する必要がある。

\section{Sub-reaction heat: $Q_{s}$}

$\mathrm{Ni}$-MH電池の代表的な充電プロファイルをFig. 5に示す。こ

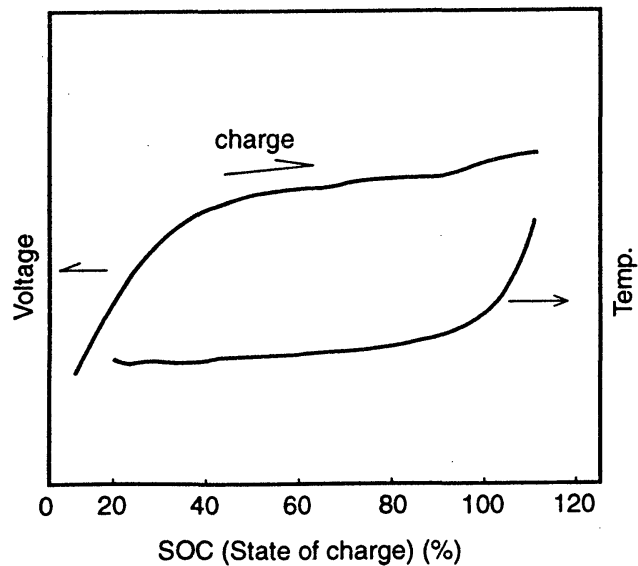

FIG.5. Typical charge profiles of Ni-MH batteries.
こでは充電後期から (1) 式および (2) 式の主充電反応以外 に、(12)式で示されるアルカリ電解液の溶媒である水の分解 反応が生じる。この際の理論分解電圧 $E_{e}$ は $(3)$ 式および $(5)$ 式から(13)式として求めることができる。

$$
\begin{aligned}
& \mathrm{H}_{2} \mathrm{O} \rightarrow \mathrm{H}_{2}+1 / 2 \mathrm{O}_{2}+Q_{2} \\
& E_{\mathrm{e}}=-(\Delta H-T \Delta S) / n F
\end{aligned}
$$

(12)式で示される $\Delta H$ は $285.9 \mathrm{~kJ} / \mathrm{mol} 、 T \Delta S$ 項は $25^{\circ} \mathrm{C}$ 条件 下で-48.6kJ/mol、またnは 2、Fは96487クーロン $(96.4 \mathrm{~kJ} /$ V)であるから、(13)式より理論分解電圧 $E_{e}$ は1.23Vとなる。す なわち、 $25^{\circ} \mathrm{C}$ 条件下では充電電位が1.23Vに到達すると副 反応である水の分解を生じることになる。しかし実際の充電 では、主反応の反応効率が充電後期から低下してくるため、 この臨界電位に到達する前から副反応を伴い始めることおよ び臨界電位を超えても正極での酸素発生過電圧の影響で、す ぐには副反応のみに転移していかないなど、実際面ではより 複雑になる。正極の酸素発生過電圧で副反応生成が支配され る理由は、密閉型Ni-MH電池では反応制御を目的として正極 容量に対し負極容量を大きく設計するため、その結果として 正極容量支配となることで充電反応が正極側で早く終了する ことによる。

さて上記したように副反応(12)式により、正極側で生じた 酸素は対極である負極の水素と反応し水を生成するが、これ は再結合反応と称され、電解液の水に帰る反応である。すな わち(12)式の逆反応で(14)式となり、この時 $Q_{3} に$ 相当する水 の生成熱-285.9kJ/molを生じるため、これが充電後期から過 充電にかけての電池の発熱として現れる。

$$
2 \mathrm{H}+1 / 2 \mathrm{O}_{2} \rightarrow \mathrm{H}_{2} \mathrm{O}+\mathrm{Q}_{3}
$$

したがって、過充電を長く続ければ続けるほど発熱の程度 が増幅され、結果として電池温度を自ら上げることになる。 電池の充電時電流を $I_{c}$ とすれば、これに伴う単位時間当たり の副反応生成熱Q $Q_{s}$ 、(15)式のように計算できる。すなわ ち、単位時間当たりの発熱量は充電電流の関数になる。

$Q_{s}=285.9[\mathrm{~kJ} / \mathrm{mol}] /(96487[\mathrm{~A} \cdot \mathrm{s} / \mathrm{mol}] / 3600[\mathrm{~s} / \mathrm{h}])$

$$
\cdot 1 / 2 \cdot I_{c}=5.334 \cdot I_{c}[\mathrm{~kJ} / \mathrm{h}]
$$

\section{Joule heat: $Q$}

電池の内部抵抗に依存する発熱がジュール熱として現れる が、(10)式に示したように内部抵抗は電気的抵抗と分極に基 づく反応抵抗とから構成され、そのトータルとしての発熱を 生じる。後者の発熱はIII.B.2.に示した通りであるが、電気 的抵抗成分の単位時間当たりのジュール熱 $Q_{j}$ は、放電電流を $I_{d}$ とすると (16)式で示される。充電時は充電電流 $I_{c}$ で置き換 えるだけで同一である。

$$
Q_{j}=I_{d}^{2} \cdot R_{e}[\mathrm{~W}]=3.595 \cdot I_{d}^{2} \cdot R_{e} \quad[\mathrm{~kJ} / \mathrm{h}] \quad(16)
$$

したがって、このジュール熱を下げるためには電池の電気 的抵抗成分 $R_{e}$ をできるだけ小さくする材料設計と構造設計が 必要になる。電気的抵抗成分は集電体と電極活物質間をつな ぐ電流ネットワークや非導電材であるセパレータ、あるいは 電解液などが支配的になる。

$R_{t}$ 成分の抵抗はFig. 6 に示す通り放電状態 (DOD)により変化 し、DOD値の大きいゾーンで増大する。この原因はFig.7に示 す通り、正極活物質であるオキシ水酸化ニッケルの導電率が 格子欠陥濃度である酸化值に比例し、このためオキシ水酸化 ニッケルの還元(放電)に伴い導電率が低下するためである。 また、電解液の電気伝導度は温度によってFig. 8のように変 化するため、電池温度が低温側にシフトすると電池の内部抵 抗が増大することになる。 


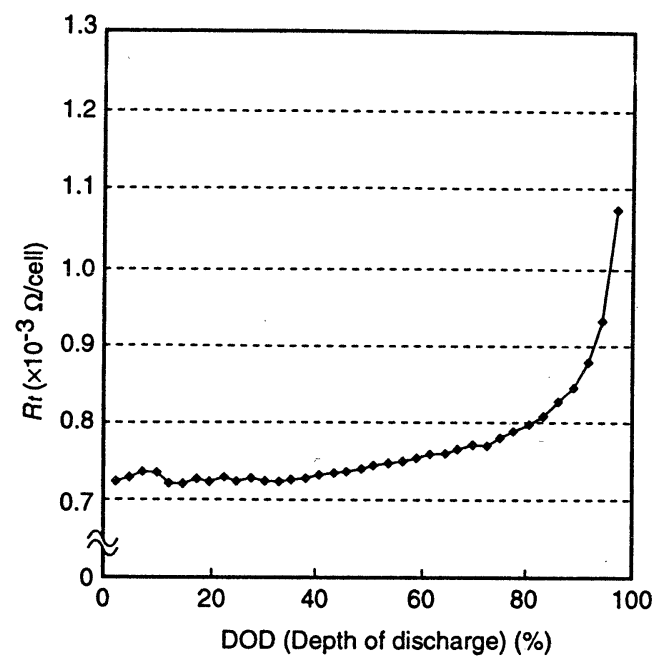

FIG.6. Dependence of internal resistance: $R_{t}$ on DOD.

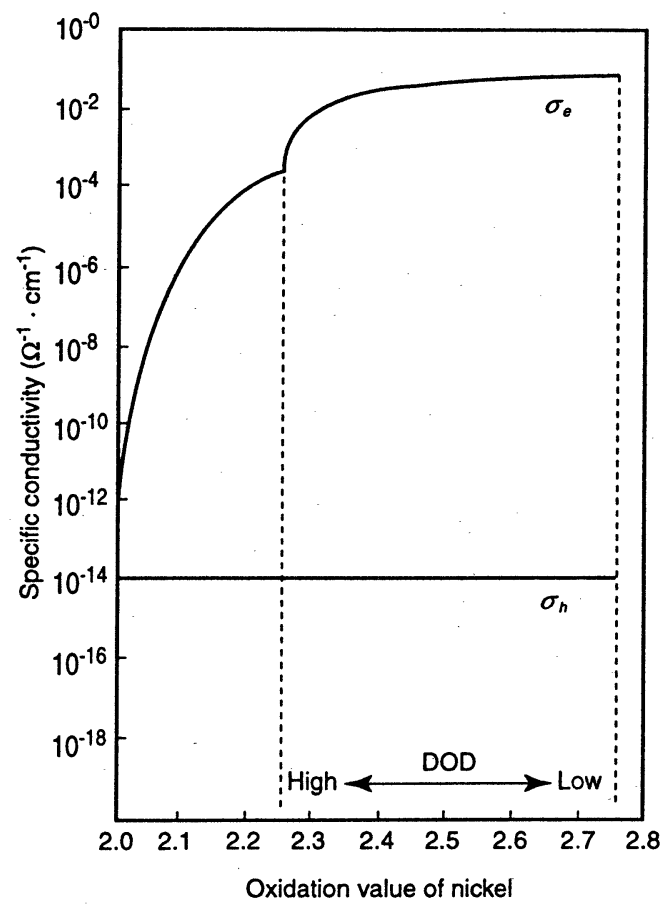

FIG.7. Relationship between oxidation value of $\mathrm{NiOOH}$ and electron conductivity $\left(\sigma_{e}\right)$, hole conductivity $\left(\sigma_{h}\right){ }^{2}$

\section{Heat income and outgo}

(1) 副反応を伴わない充電時の熱収支

この時の単位時間当たりの熱収支 $Q_{c}$ は (17)式で表現され

る。この時、Q $Q_{S}$ はゼロである。

$$
\begin{aligned}
Q_{c}= & Q_{\mathrm{r}}+Q_{s}+Q_{p}+Q_{j}=0.547 \cdot I_{c}+3.595 . \\
& I_{c}{ }^{2} \cdot R_{p}+3.595 \cdot I_{c}{ }^{2} \cdot R_{e}=0.547 \cdot I_{c}+ \\
& 3.595 \cdot I_{c}{ }^{2} \cdot R_{t}[\mathrm{~kJ} / \mathrm{h}]
\end{aligned}
$$

(2) 副反応のみの充電時の熱収支

この時の単位時間当たりの熱収支 $Q_{c}$ は(18)式で表現され る。この時、Q $Q_{r}$ はゼロである。

$Q_{c}=Q_{r}+Q_{s}+Q_{p}+Q_{j}=5.334 \cdot I_{c}+3.595 \cdot I_{c}{ }^{2} \cdot R_{t}[\mathrm{~kJ} / \mathrm{h}] \quad(18)$ すなわち、（17）式で観測される電池反応熱 $Q_{r}$ に対し、(18)式 の副反応熱 $Q_{s}$ の比率は約 10 倍にも達し、圧倒的に高くなる。

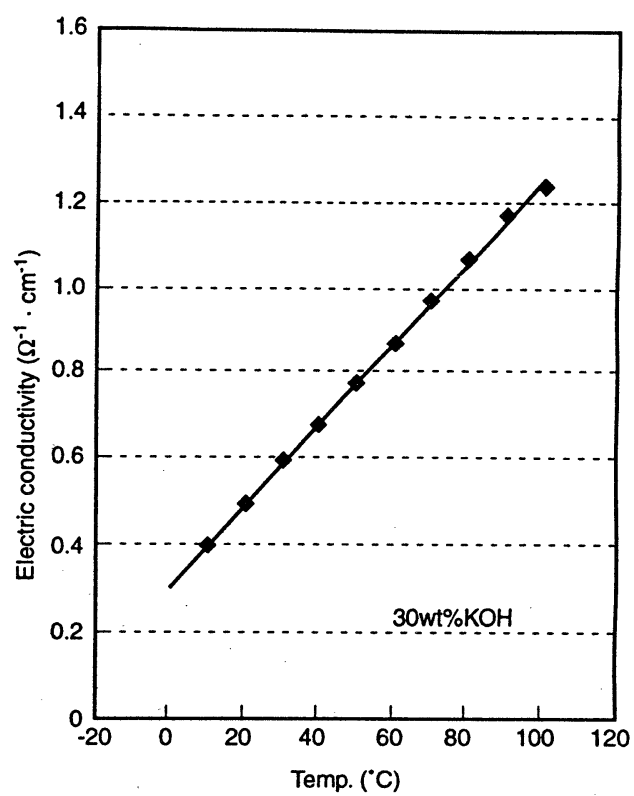

FIG.8. Temperature dependence of electric conductivity of electrolyte.

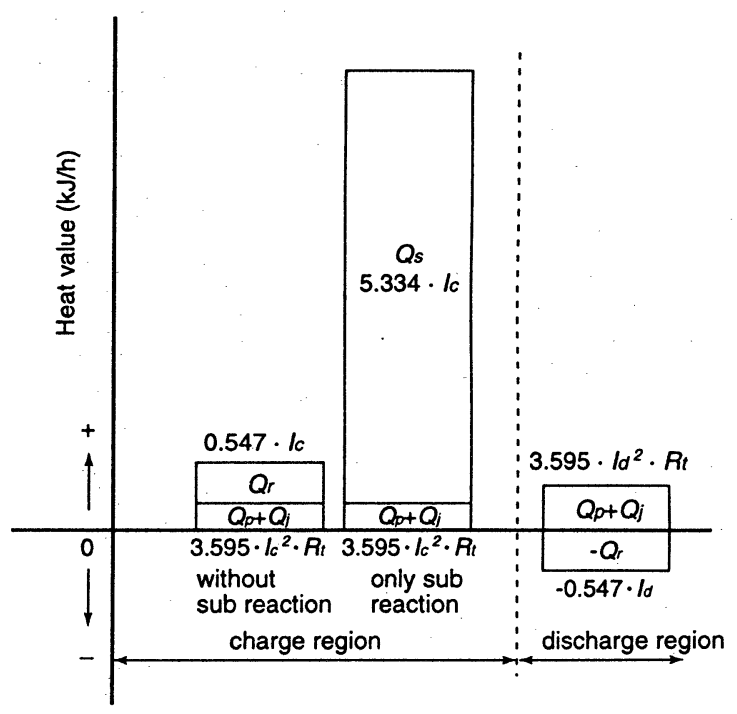

FIG.9. Heat income and outgo model of Ni-MH batteries during charge and discharge process.

\section{( 3 ) 放電時の熱収支}

この時の単位時間当たりの熱収支Q $Q_{d}$ は (19)式で表現され

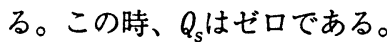

$Q_{d}=Q_{r}+Q_{s}+Q_{p}+Q_{j}=-0.547 \cdot I_{d}+3.595 \cdot I_{d}^{2} \cdot R_{t}[\mathrm{~kJ} / \mathrm{h}] \quad$ (19) この関係をFig. 9 に示す。副反応を伴わない充電領域で は、電池反応熱とジュール熱の合算値となるが、副反応のみ になる段階で(14)式のリコンビネーションによる発熱が支配 的となり、充電時には二段階の発熱を考慮する必要がある。 但し、厳密にはこの中間段階も存在する。これに対し放電時 には、ジュール熱と吸熱方向の電池反応熱となり、この結 果、(20)式が成立する場合に全体の発熱量が理論上ゼロにな る計算である。

$$
I_{d} \cdot R_{t}=0.152
$$




\section{Experiment of heat behavior of Ni-MH battery}

“HONDA EV PLUS”に搭載されているNi-MH電池の熱挙動を 実測することにより、上記理論計算との相関性について考察 した。

(1)副反応を伴わない充電時の熱収支

(17)式に対し $I_{c}$ とR を定めれば単位時間当たりの発熱量が 計算される。充電電流 $I_{c}$ は $4 \mathrm{~kW}$ の定電力充電によるため、 Fig.10のようにSOCに応じて変動する。また、電池の内部抵 抗 $R_{t}$ も前記した理由により、図のごとく変化するため、結果 として単位時間当たりの総発熱量はFig. 11のように計算され る。さらにこの時の実測值を図中に示す。計算値と実測値は ほぼ一致を見るが、実測値の中でSOC100\%の手前から右上が りになるのに対し、計算値でフラットになる理由は以下の通 りである。計算上では充電域 $100 \%$ までは副反応は進行しな

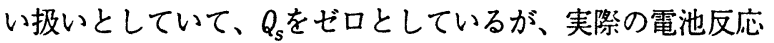
では充電後期から副反応を伴うことで $Q_{s}$ 無視できなくなる ためである。しかしいずれにせよ、この領域での発熱は以降 の過充電領域における発熱に比べかなり小さい值をとる。そ

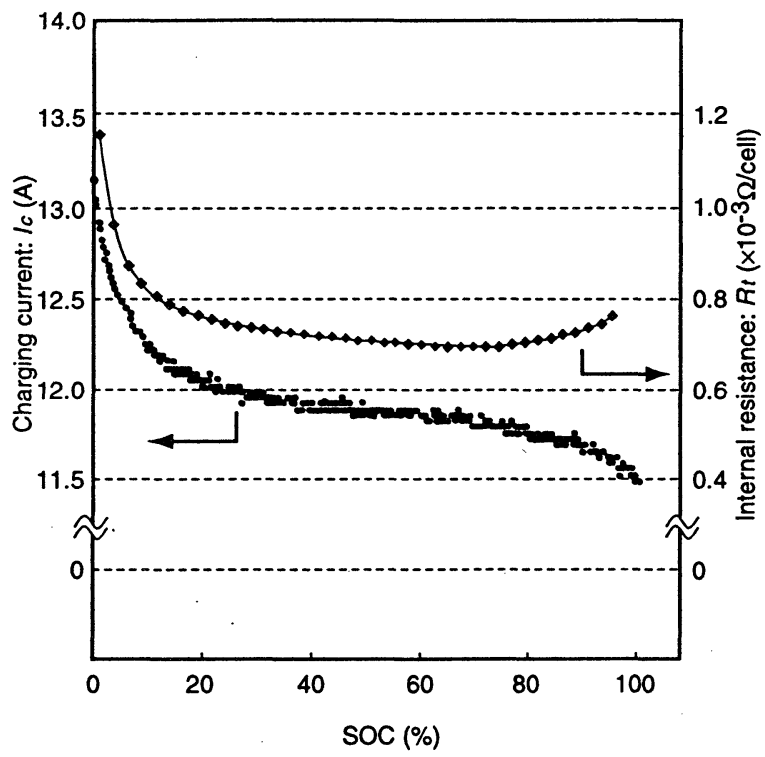

FIG.10. Charging current: $I_{c}$ profile with $4 \mathrm{~kW}$ constant power and internal resistance: $R_{t}$ in accordance with SOC.

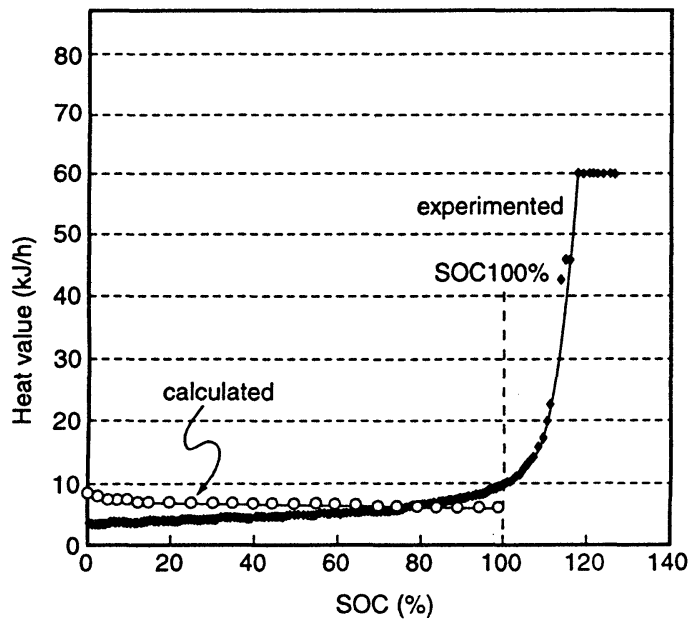

FIG.11. Comparison of calculated heat with experimented heat value: $Q_{c}$ during charge without sub reaction.
の大部分はジュール損失熱 $Q_{j}$ ではなく、反応熱 $Q_{r}$ である。例 えば、SOC50\%における充電電流Icは11.9A、R $R_{t}$ は $7 \times 10^{-4} \Omega$ であるから、(17)式より $Q_{r}$ は $6.5 \mathrm{~kJ} / \mathrm{h} 、\left(Q_{p}+Q_{j}\right)$ は0.36kJ/hと いう関係になり、反応熱はジュール熱の18倍に相当する結果 となる。

(2) 副反応のみの充電の熱収支

(18) 式に従い充電電流 $I_{c}$ および内部抵抗 $R_{t}$ を定め、単位時 間当たりの発熱量を求める。このとき $I_{c}$ は11.5A、R $10^{-4} \Omega$ であるから、 $Q_{s}$ は $61.34 \mathrm{~kJ} / \mathrm{h} 、\left(Q_{p}+Q_{j}\right)$ は $0.38 \mathrm{~kJ} / \mathrm{h}$ とい う関係になり、副反応熱はジュール熱の161倍にも達する。

一方、Fig.11の単位時間当たりの発熱量実測データを、時 間に対し積分した総発熱量としてFig. 12に示す。グラフの勾 配は単位時間当たりの発熱量に相当するが、この勾配からの 変曲点が105\%近辺に観測される。

(3) 充電時発熱の上限

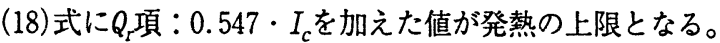
すなわち、実際には有り得ない条件であるが主反応と副反応 が各々最大に進行している場合に相当する。Q.は6.29kJ/hで あるから、この場合のトータルの単位時間当たりの発熱量は $68.01 \mathrm{~kJ} / \mathrm{h}$ となる。図の勾配からもこの結果は矛盾しないこ とが確認され、計算による発熱量予測の確からしさが証明さ れる。

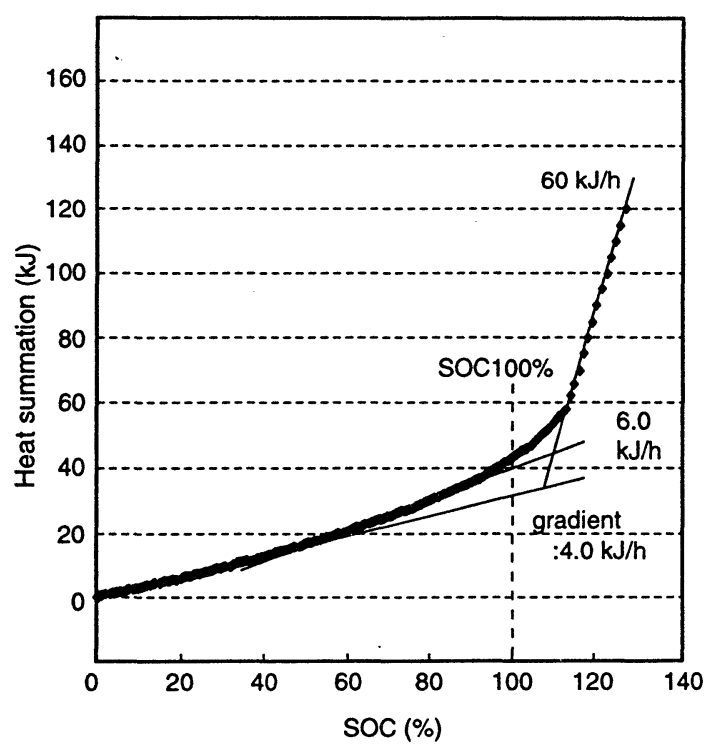

FIG.12. Heat summation obtained by the experimented data in Fig.11.

\section{CONTROL TECHNOLOGY OF HEAT GENERATION}

III.B.5. (3)に述べたように、Ni-MHの放電側では、電池反 応熱が吸熱方向となる効果のために、実際の使用段階では大 きな問題とならない。発熱制御は主に充電側の議論であり、 以下の論理で表現できる。すなわち、Ni-MH電池の場合の電 池反応熱 $Q_{r}$ は原理上避けられないわけで、発熱制御技術とし てはジュール損失熱 $Q_{j}$ と副反応熱 $Q_{s}$ の制御が重要になる。但 し、電池反応熱 $Q_{r}$ を含めたすべての発熱項に対し充電電流が 関与するため、充電電流を大きくすればするほど発熱の増大 につながることが容易にわかる。したがって急速充電のシス テムは発熱を顕著に促進させる外的因子になる。ジュール損 失熱の低減は、III. B. 2. および而. B. 4. に述べた通りで、反応 抵抗と電気的抵抗成分の低減に他ならない。 
III.B.5.に示したごとく、充電時の発熱は副反応によるリ コンビネーションで加速されることから、Q $、$ の制御が極めて 効果的である。そのための制御技術としては、1)リコンビ ネーションを発生しない段階での充電制御、2 $)$ 充電電流の 抑制、3)リコンビネーションが起こりにくくなるための酸 素発生過電圧の制御が挙げられる。しかし1)の方法ではフ ル充電することができなく、電池の保有する容量を最大限取 ク出せなくなる。当然のごとく、電池の充電エネルギー効率 は $100 \%$ にはならないため、電池容量を最大に取り出すため には100\%以上の充電が必要になるが、この場合にはいかに 最小限の過充電領域で充電制御できるかがキーになる。2) の場合では、電気自動車の充電時間を考えた場合、最大でも 8 時間以内の充電が必要となり、例えば100Ah級のNi-MH電池 の場合には $12.5 \mathrm{~A}$ 以上の平均電流が要求される。

さて 3 )の制御技術は電池開発にあたって基本的なブレー クスルー技術となる。Figure 5に示したように、充電後期の プロファイルが決め手になる。この時、正極では(21)式に従 い酸素が発生するが、この酸素発生の度合いは正極の活物質 組成に支配される。すなわち、正極組成系によって酸素発生 を遅らすことのできる過電圧 $\eta$ を大きくることが可能であ る。この関係を電位モデルを用いFig.13に示す。

$$
20 \mathrm{H}^{-} \rightarrow 1 / 2 \mathrm{O}_{2}+\mathrm{H}_{2} \mathrm{O}+2 \mathrm{e}
$$

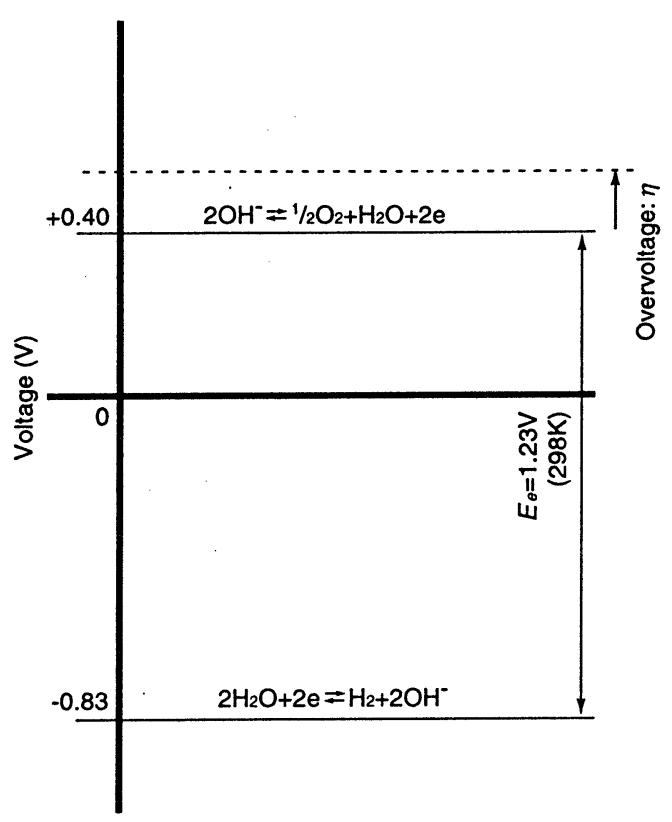

FIG.13. Voltage model of oxygen generation on positive electrode and hydrogen generation on negative electrode.

電気化学反応速度を表す電流密度を $I$, 電極反応の触媒性 を示す交換電流密度を $I_{0}$ とすれば、酸素発生過電圧 $\eta$ との関 係は(22)式で表される。ここで $z$ は応の透過係数である。

$$
I=I_{o}\left\{\exp (z n F \eta / R T)-\exp \left[-(1-z)_{n} F_{\eta} / R T\right]\right\}
$$

さらに $k_{o} を$ 標準速度定数として表せば、(21)式に対する交 換電流密度 $I_{o}$ は (23)式のように表現できる。

$$
I_{o}=n F k_{o}\left[\left(\mathrm{OH}^{-}\right)^{2}\right]^{1-2} \cdot\left[\left(\mathrm{O}_{2}\right)^{1 / 2} \cdot\left(\mathrm{H}_{2} \mathrm{O}\right)\right]^{z}
$$

(21)式の正方向の分極に対する過電压 $\eta$ は、(22)式の第 1 項により表され、(24)式となる。

$$
\eta=R_{t} / n F \cdot \ln \left(I / I_{o}\right)
$$

正極組成の開発は (21) 式の反応の交換電流密度 $I_{o}$ 小さく する方向での材料設計であり、その結果、電荷移動に対する 障壁を大きくし、(21)式の反応を起こしにくくする効果であ る。日本では1980年代の前半から研究され、カドミウム (Cd) や亜鉛 $(\mathrm{Zn})$ の添加が効果的であることが確認され実用化され た。 ${ }^{4}$ また最近ではZnより効果的な物質としてイットリウム 酸物 $\left(\mathrm{Y}_{2} \mathrm{O}_{3}\right)$ やイッテルビウム酸化物 $\left(\mathrm{Yb}_{2} \mathrm{O}_{3}\right)$ が開発され、実用 化されている。5.6この効果モデルはFig. 14に示す通りで、 $\Delta \mathrm{E}$ 大゙大きいほどその効果が大きくなる。また、この制御技 術は高温側でより顕著になるが、その理由は以下による。 $E_{e}$ は(13)式にあるように温度Tに依存し、高温側になればなる ほど $E_{e}$ が低下し、正極側での酸素発生が起こり易くなるため である。例えば電池温度が $45^{\circ} \mathrm{C}$ の場合の水の理論分解電圧 $E_{e}$ は1.21Vまで低下する計算になる。

この制御技術を適用すれば、電池自体からの発熱を最低限 に抑えることが可能となり、よって発熱抑制のための冷却能 力と冷却システムを軽減できる利点が生じる。その分、充電 時の電力消費の低減が可能で電気自動車のエネルギー効率の 向上に貢献でき、結果的に電気自動車の価値をさらに高める ことになる。今後の開発方向も、より高温側での充電エネル ギー効率が高められる正極技術の研究に期待がかかる。

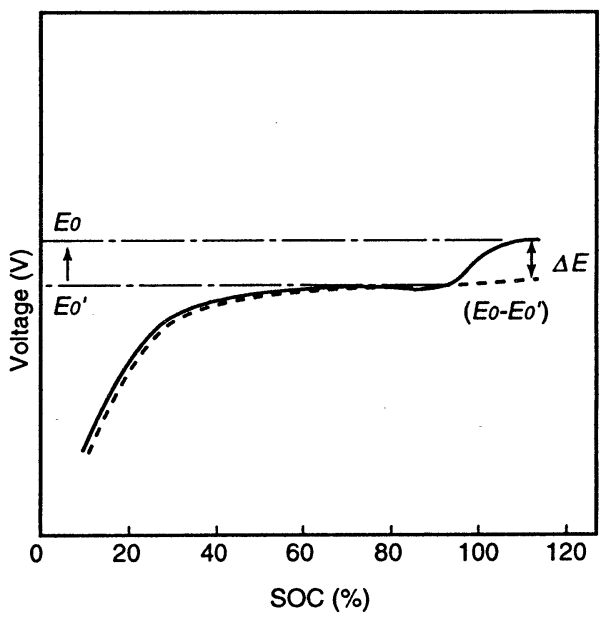

FIG.14. Profile model of oxygen generation voltage during charge process.

\section{EFFECT OF HEAT CONTROL}

発熱制御により得られる効果は多くあり、以下にその概要 を記す。発熱を抑えることで出現する効果には、1)電池寿 命の延命、2 ) 充電受入性向上によるエネルギー効率の向 上、3) 冷却補機システムの能力軽減による電力消費の低減 とレンジの確保、などが挙げられる。

一般に、電池温度が上昇すると電池の寿命が低下すること は良く知られているが、この原因は単純ではない。例えば高 温下での負極合金の酸化、電解液の局所分散やセパレータの ドライアップなどが複合的に絡んだりする場合があり、温度 パラメータを有するアレニウスの式に必ずしも乗らない場合 が多い。よってこの温度に対するタフネス向上に向けては、 負極合金の耐酸化性の向上、七パレータの電解液保持性の向 上が解決策のひとつになる。3)の冷却補機システムの能力 
設計は、電池の発熱とそれによる電池の性能低下の度合いに よって決定されるが、冷却能力を増大すれば寿命延命に効果 的である反面、それに要す電気エネルギーは充電時の電力消 費を増大させたり、電気自動車のレンジをその分低下させる 結果になる。Figure 15に電池の充電に伴う冷却作動モデル と、その時の冷却効果を示す。したがって、電池本体の発熱 をできるだけ制御できる技術の導入と、必要な冷却能力の設 計は重要な要素のひとつである。

2 ) 項にあげたエネルギー効率の向上に関しては、発熱の 程度と直接関連付けられる。Figure 16には発熱量と充電効 率の相関を示す。従来型のNi-MH電池を標準とし、これに対 し電池発熱量を抑制する目的で充電効率を高める改良型を試 作し、その差異を比較する。充電開始時の電池温度を $45^{\circ} \mathrm{C}$ と 設定したところ、改良型の電池はSOC40\%以上の領域で標準 型電池に比較して充電効率が 5 \%程度高くなることを確認し た。より高温側ではこの差はさらに大きくなることも確認さ れている。SOC40\%以下の領域では差が現れない理由は、副 反応の進行がほとんどないことに由来する。この両者間の電 池に対する発熱量の差は図中に示した通り、効率向上の改良 型で発熱量が抑えられていることがわかる。この発熱量の差

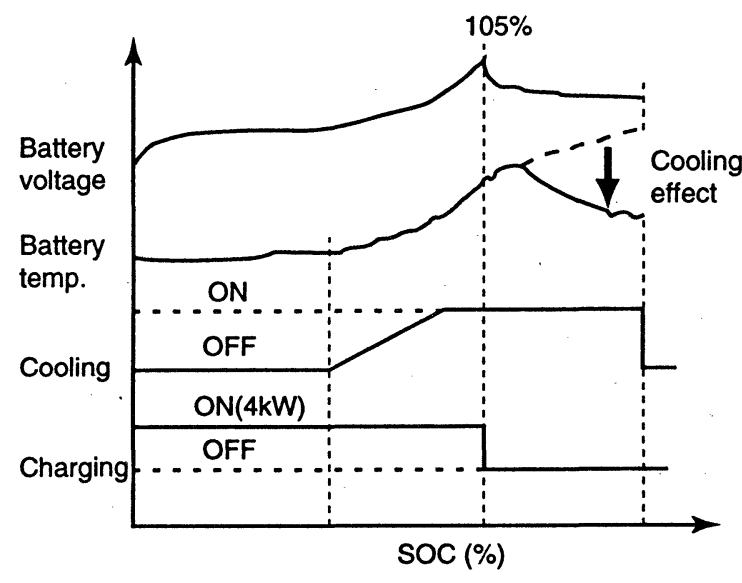

FIG.15. Typical pattern model of charging anc cooling.

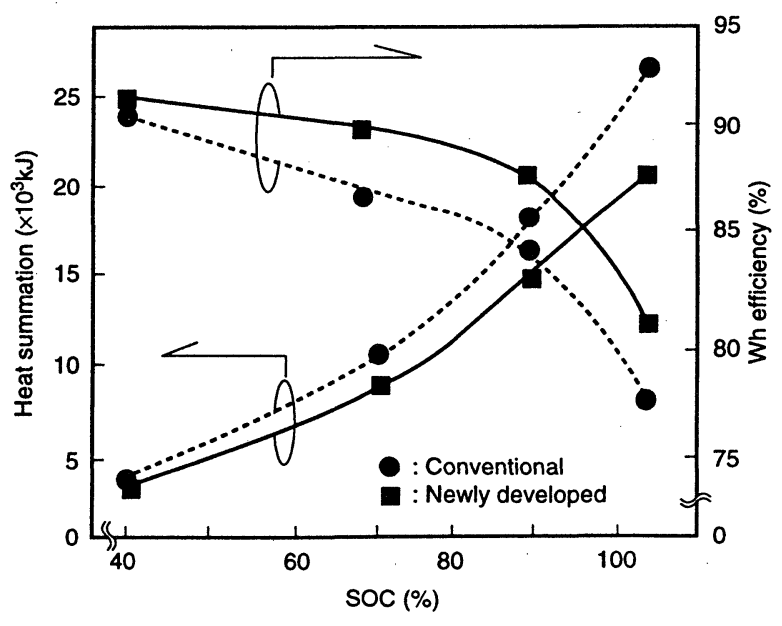

FIG.16. Relationship between total heat value and energy charge efficiency.
は、充電効率の差とほほ一致し相関性が高いことを示唆する ものである。SOC90\%のゾーンで両者の電池の充電効率の差 は約 4 \%であるが、このゾーンでの総発熱量の差： $\Delta Q$ Q 約 $1 \mathrm{kWh}$ となる。27kWh容量の組電池を対象にしていることか ら、発熱量の差がもたらすエネルギー効率：Wheff より計算される。

$$
W h_{\text {eff }}=\Delta Q / 27 \cdot 0.9 \cdot 100(\%)
$$

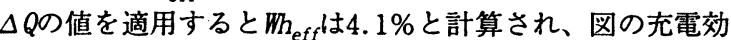
率の差、約 4 \%と一致する。ゆえに充電効率の向上による発 熱制御技術は、充電以外に消費される電力を抑制することが 可能で、総合的な価值を高める結果をもたらす。

電池の充電効率を向上させ電池の発熱を㧕制すること、取 りも直さず電池系のエントロピ変化： $\Delta S$ 小さくすること を意味し、よって (3)式で表示されるギブスの自由エネル ギー変化： $\Delta G$ Gきくすることである。Figure 17に示すよ うに、この考え方は電池の種類がいかにあろうと共通した要 素であり、今後の高性能電池の研究開発に不可欠な基本要素 と表現できる。

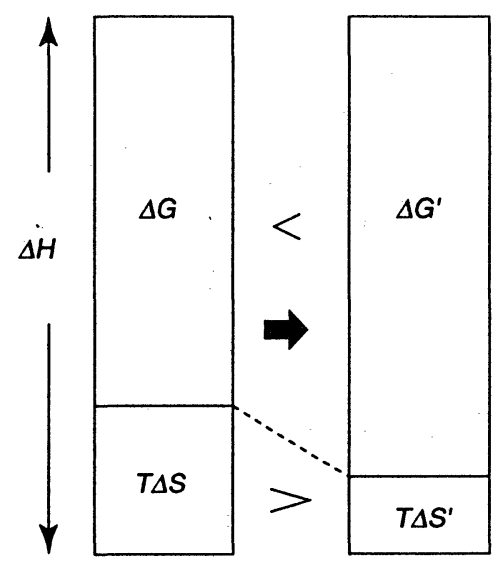

FIG.17. Basic concept of battery development.

\section{CONCLUSION}

以上のように、電池の発熱は性能面、制御技術あるいはエ ネルギー効率にと大きく影響する因子であり、よって発熱制 御は電池材料研究、電池構造設計、搭載技術のいずれにとっ ても極めて重要な要素技術である。著者はこれまで、「熱を 制するものは電池を制す」という格言を発しながら、電池 メーカとの共同的な開発の中で、その方向性を提示してき た。この結果、現在、電気自動車用電池として奏用に供され ている電池は、開発当初に比べて飛躍的に発熱制御が向上し た特性に進化してきた。

しかし熱については、まだ多くの解決すべき課題を抱えて おり、様々な角度からの取り組みと一層のブレータスルーが 必要とされていることも事実である。したがっで電池材料の 開発はもちろんのこと、発熱を起こしにくい使用側での制御 技術も併せて確立していく必要がある。

21世紀は「エントロピの時代」とも言われるが、言い換えれ ばエントロピを増大させないような電池システムの研究開発 がますます活発になっていくものと推測される。その意味で も自動車メーカと電池メーカとが一体となった開発がますま す必要になっていく。 


\section{SYMBOL}

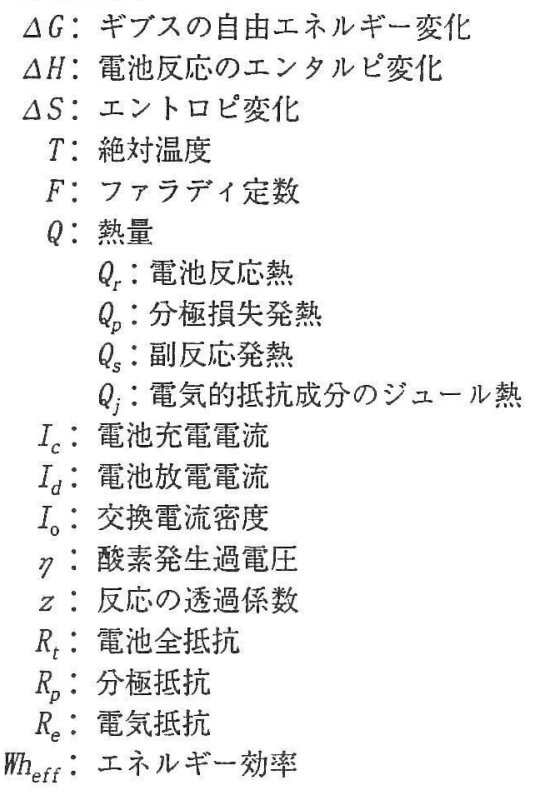

\section{REFERENCES}

1 Y. Saito, K. Kanari, K. Takano and T. Masuda, Thermal Measurement of a Lithium Secondary Battery, Research of the Electrotechnical Laboratory, 60, No.12, 771 (1996).

2 Denchi Binran, (Maruzen, 1990) pp. 230-231.

3 K.Yagi, M.Onodera, K. Nakaya and N.Sato, Electrochemical Evaluation of Metal Hydride Electrodes, Zeitschrift für Physikalische Chemie, 183, 1297 (1994).

4 M. Oshitani, K. Hasegawa and H. Yufu, Alkal ine Battery with a Nickel Electrode, US Patent, 4,985,318 (1991).

5 K. Ohta, Hydrogen and Metal Hydride Batteries, The Electrochemical Society Inc., NJ., 296 (1994).

6 M. Ohnishi, M. Oshitani, K. Takeshima, H. Kawai and M.Nakane, Development of Nickel Metal-Hydride Battery for Electric Vehicles, Proceedings of The $13^{\text {th }}$ International Electric Vehicle Symposium, Osaka, 51 (1996).

\begin{tabular}{|c|c|}
\hline 著者紹介 & ; 佐藤 登（さとうのぼる） \\
\hline 1978 年 & $\begin{array}{l}\text { 横浜国立大学大学院 } \\
\text { 一学研究科修了 }\end{array}$ \\
\hline 同年 & 本田技研工業傣入社 \\
\hline 現在 & $\begin{array}{l}\text { (秼本田技術研究所 } \\
\text { チーフエンジニア }\end{array}$ \\
\hline 1988 年 & 東京大学工学博士 \\
\hline 1999 年 & $\begin{array}{l}\text { “Who'sWho in the World” } \\
\text { (世界人名事典) に掲載 }\end{array}$ \\
\hline
\end{tabular}

